\title{
Geminivirus Resistance in Transgenic Tobacco Expressing Mutated BC1 Protein
}

\author{
Y.-P. Duan, ${ }^{1}$ C. A. Powell, ${ }^{2}$ S. E. Webb, ${ }^{3}$ D. E. Purcifull, ${ }^{1}$ and E. Hiebert ${ }^{1}$ \\ ${ }^{1}$ Department of Plant Pathology, University of Florida, Gainesville 32611-0680, U.S.A.; ${ }^{2}$ Indian River REC, \\ Ft. Pierce, FL 34945-3138; ${ }^{3}$ Department of Entomology, CFREC, Leesburg, FL 34748-8232, U.S.A. \\ Received 24 December 1996. Accepted 24 March 1997.
}

\begin{abstract}
Tobacco explants were transformed by Agrobacteriummediated transformation with sense and antisense constructs of the movement protein genes $(B C 1$ and $B V 1)$ of tomato mottle geminivirus (TMoV). Transgenic plants were tested for virus resistance either by exposure to viruliferous whiteflies carrying TMoV or cabbage leaf curl geminivirus (CabLCV) for a 72-h inoculation period or by continuous exposure to $\mathrm{TMoV}$ during the life of the plants. The transgenic lines were scored for disease symptoms, and virus replication and distribution were determined by enzyme-linked immunosorbent assay and dot blot hybridizations. Transgenic plants which expressed a mutated form (identified in a previous study) of the $B C 1$ gene showed TMoV and CabLCV resistance. Three resistant phenotypes were observed: a delay in symptom development, a recovery from early symptoms, and an absence of virus symptoms at all stages. Geminivirus was detected in inoculated leaves but was not readily detected in leaves beyond the inoculation sites in the highly resistant plants. The geminivirus resistance conferred by expression of the spontaneously mutated $B C 1$ gene (detected after transformation) in transgenic tobacco may involve transdominant negative interference.
\end{abstract}

The recent introduction of a new, polyphagous biotype of the whitefly vector Bemisia tabaci (Gennadius) into the New World (reviewed by Brown et al. [1995]) has resulted in more frequent and more widely distributed geminivirus problems in vegetable and fiber crops. Concurrently, apparently new whitefly-transmitted geminiviruses have caused serious losses in tomato production worldwide (Brown and Bird 1992). Tomato mottle virus (TMoV), an example of a new geminivirus pathogen, is a typical bipartite geminivirus (Abouzid et al. 1992b) first found in Florida in 1989. The virus was found widespread in tomato production areas in Florida, with an incidence as high as $95 \%$, and caused an estimated loss of $\$ 125$ million in tomato production in southwest Florida in 1990 1991 (Polston et al. 1993). No tolerant or resistant cultivars are currently available, and disease control in Florida relies on frequent sprays of insecticides or soil applications of imidacloprid, a systemic insecticide (Polston et al. 1996). This dis-

Corresponding author: E. Hiebert; Phone: 352-392-7246; Fax: 352-3926532; E-mail: EHI@GNV.IFAS.UFL.EDU ease management approach is highly vulnerable to the development of insecticide resistance. Other factors of concern are the high cost and environmental exposure to widespread insecticide applications.

Recent advances in molecular biology have led to the development of pathogen-derived resistance, in which the expression of a pathogen-derived gene or sequence in a plant provides resistance to the pathogen (Sanford and Johnson 1985). Many examples of this engineered resistance to RNA plant viruses have been presented (reviewed by Beachy [1993] and Lomonossoff [1995]). Reports of engineered virus resistance in transgenic plants expressing geminivirus DNA sequences are more limited. Defective viral DNA, antisense AC1 (replication-associated protein) gene, defective AC1 protein, defective movement protein, and coat protein have been demonstrated to confer geminivirus resistance (Stanley et al. 1991; Day et al. 1991; von Arnim and Stanley 1992a; Kunik et al. 1994; Hong and Stanley 1996; Noris et al. 1996). However, none of the previously described transgenic plants had an immune response, and the conferred resistance was moderate, with a narrow resistance spectrum.

Two movement proteins, BC1 and BV1 (previously known as BL1 and BR1, respectively), encoded by DNA-B of bipartite geminiviruses, are required for viral infectivity and systemic infection (von Arnim and Stanley 1992b; Smith and Maxwell 1994; Haley et al. 1995; Ingham et al. 1995). The $\mathrm{BC} 1$ protein is responsible for cell-to-cell movement of these viruses (Noueiry et al. 1994) and is the only determinant of pathogenicity (Pascal et al. 1993; Ingham et al. 1995). In a recent study of tobacco transformed with the TMoV $B C l$ gene Duan (1996) described a mutated form of $B C 1$ which had a marked effect on the phenotype. The mutated $B C l$ gene identified in one transgenic line had a major deletion of 119 amino acid residues at the $\mathrm{C}$ terminus and a recombination resulting in the addition of 26 amino acid residues from an unidentified origin in the open reading frame. Segregation of the progeny of this line showed that the majority of the $T_{1}$ plants had a mild to asymptomatic phenotype, while approximately onethird had the severe-symptom phenotype expected with $B C 1$ gene expression. The asymptomatic, mutated $B C 1$ suppressed the phenotypic expression of the symptomatic $B C 1$ in tobacco lines containing both copies of the $B C 1$ gene. The symptom suppression by the mutated $B C 1$ had characteristics described as "dominant negative interference" (Herskowitz 1987). Here we report that transgenic plants expressing a mutated TMoV $\mathrm{BC} 1$ protein with an asymptomatic phenotype show resistance 
to two distinct geminiviruses when tested by viruliferous whitefly inoculations.

\section{RESULTS}

\section{Transgenic tobacco expressing $\mathrm{BC} 1$ and $\mathrm{BV} 1$ proteins.}

Tobacco (Nicotiana tabacum cv. Xanthi) was transformed with sense and antisense constructs of TMoV $B C l$ and $B V I$ open reading frames (Fig. 1). Analysis of the transgenic tobacco by enzyme-linked immunosorbent assay (ELISA) for neomycin phosphotransferase II and polymerase chain reaction (PCR) amplification with specific primers identified 19 $\mathrm{T}_{0}$ plants with sense $B C 1,16$ with antisense $B C 1,20$ with sense $B V l$, and five with antisense $B V l$. Eight of the 19 transgenic $\mathrm{T}_{0}$ plants expressing $\mathrm{BC} 1$ protein did not show any of

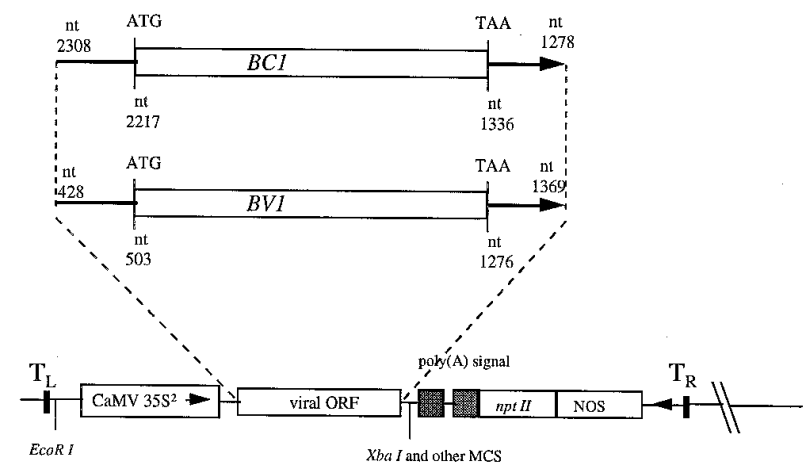

Fig. 1. Construction of an expression vector for nonstructural protein genes of tomato mottle geminivirus with the plasmid pKYLX71:35S $\mathrm{S}^{2}$. The $B C 1$ and $B V 1$ open reading frames, including their $5^{\prime}$-leading and $3^{\prime}$-nontranslated intergenic sequences, were amplified by polymerase chain reaction (PCR) using primers with HindIII restriction sites for subsequent cloning. Each of these PCR products was cloned into the pGEM-T vector. The $\mathrm{BC} 1$ and $\mathrm{BV} 1$ clones were digested with HindIII and then ligated into the pKYLX71:35S $\mathrm{S}^{2}$ vector to generate both sense and antisense orientations of $B C l$ and $B V 1$ gene construct in pKYLX$71: 35 \mathrm{~S}^{2}$. The positions of translational start and termination codons are indicated. The left and right T-DNA border sequences of the expression vectors are represented by $T_{L}$ and $T_{R}$. The cauliflower mosaic virus $35 \mathrm{~S}$ promoter (CaMV $35 \mathrm{~S}^{2}$ ), nos promoter (NOS), neomycin phosphotransferase II (npt II), polyadenylation signal (poly(A) signal), and multiple cloning sites (MCS) are noted; $n t=$ nucleotide.

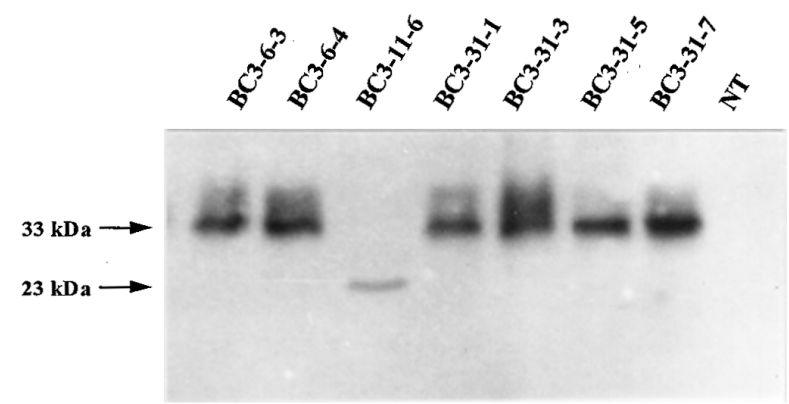

Fig. 2. Western blot analysis of transgenic $T_{1}$ tobacco plants (uninfected) expressing the $B C l$ gene. Extracts from young leaf tissue were fractionated as described in Materials and Methods. P30 fractions ( $8 \mu \mathrm{l})$ from transgenic plants and from a nontransformed control plant (NT) were subjected to sodium dodecyl sulfate-polyacrylamide gel electrophoresis and transferred to a nitrocellulose membrane. The $\mathrm{BC} 1$ protein was detected with anti-BC1 polyclonal antiserum. The sizes of the full-length $(33-\mathrm{kDa})$ and the truncated $(23-\mathrm{kDa}) \mathrm{BC} 1$ protein are indicated on the left. the viruslike symptoms expected with the expression of this gene in transgenic plants (Duan 1996). Tobacco transformed with antisense $B C l$ and sense and antisense $B V l$ was indistinguishable in phenotype from nontransformed tobacco. The level of BV1 protein detected in the sense $B V 1$ transgenic tobacco (data not shown) was lower than the level of $\mathrm{BC} 1$ protein in the sense $B C l$ transgenic tobacco (Fig. 2) when compared with the detection of these proteins in extracts from $\mathrm{TMoV}$-infected tissues. High levels of $\mathrm{BC} 1$ protein were detected in all $\mathrm{T}_{1}$ lines except one (BC3-11-6), in which a low level of a smaller protein ( $23 \mathrm{kDa}$ versus the expected $33 \mathrm{kDa})$ was detected, even though RNA blots indicated a similarly high steady-state mRNA level for all the transgenic lines (data not shown). Previously we showed that this $B C 1$ transgene (BC1At/r; Genbank U65506) had undergone a recombinational event which resulted in an open reading frame with the deletion of 119 carboxy-terminal amino acid residues and the addition of 26 amino acids from an unknown source (Duan 1996). The low level of $\mathrm{BC} 1$ protein detection in the BC311-6 line may be due to the loss of epitopes, since more than one-third of the codons for the carboxy-terminal amino acid residues were lost during the recombinational event (Duan 1996).

Transgenic tobacco plants which express BC1 protein and have asymptomatic phenotypes show TMoV resistance.

Selected transgenic tobacco lines ( $\mathrm{T}_{1}$ generation) at the seven- to nine-leaf stage were exposed to viruliferous whiteflies carrying TMoV in the greenhouse for a 72-h access period (Table 1). All of the transgenic lines tested, except certain

Table 1. Assessment of resistance to tomato mottle geminivirus (TMoV) in $\mathrm{T}_{1}$ transgenic tobacco plants expressing different forms of the $\mathrm{TMoV}$ $B C 1$ and $B V 1$ genes

\begin{tabular}{lcc}
\hline Plant line $^{\mathbf{a}}$ & $\begin{array}{c}\text { No. of diseased plants/ } \\
\text { no. of inoculated plants } \\
\text { (no. of experiments) }\end{array}$ & $\begin{array}{c}\boldsymbol{A}_{\mathbf{4 0 5}} \text { value }^{\mathbf{c}} \text { of } \\
\text { diseased plants/ } \\
\text { asymptomatic plants }\end{array}$ \\
\hline Nontransformed & $32 / 34(6)$ & $0.665 / 0.008$ \\
BC3-6 & $3 / 20(4)$ & $0.323 / 0.011$ \\
BC3-11 & $25 / 32(6)$ & $0.583 / 0.010$ \\
BC3-31 & $9 / 30(4)$ & $0.492 / 0.007$ \\
BVas2-1 & $10 / 10(2)$ & $0.595 / \ldots$ \\
BVas2-6 & $7 / 9(2)$ & $0.603 / 0.013$ \\
BV9-15 & $15 / 15(2)$ & $0.626 / \ldots$ \\
BCas8-8 & $12 / 12(2)$ & $\mathrm{NA}$ \\
BCas8-11 & $14 / 14(2)$ & $\mathrm{NA}$ \\
BCas8-14 & $12 / 16(2)$ & $\mathrm{NA}$ \\
BV3-9 & $15 / 15(2)$ & $\mathrm{NA}$ \\
BV9-1 & $14 / 14(2)$ & $\mathrm{NA}$ \\
BV9-7 & $16 / 16(2)$ & $\mathrm{NA}$ \\
\hline
\end{tabular}

${ }^{a}$ Plant lines transformed with the TMoV $B C 1$ gene are identified by BC-, and those transformed with the $B V 1$ gene are identified by BV-. as $=$ Antisense orientation of the gene.

b The transgenic (kanamycin-resistant) and control plants at the sevento nine-leaf stage were exposed in a cage to viruliferous whiteflies for $72 \mathrm{~h}$, with approximately 100 whiteflies per plant.

${ }^{c}$ Indirect enzyme-linked immunosorbent assay (ELISA) was used to assay the inoculated plants 35 to 40 days after inoculation as described in Materials and Methods. Newly expanded leaves from individual plants were collected and homogenized in 1:5 (w/v) phosphate-buffered saline for the assay. The ELISA readings represent the mean values $\left(A_{405}\right)$ from three duplicate reactions of all diseased plants or all resistant (asymptomatic) plants in a given group. In all cases, a positive ELISA result was correlated with the appearance of viral symptoms.

${ }^{\mathrm{d}} \mathrm{NA}=$ not analyzed. 
ones expressing $\mathrm{BC} 1$ protein, were highly susceptible to TMoV. On the basis of this test and others (data not shown), we focused our analysis of virus resistance on three $B C 1$ transgenic lines, BC3-6, BC3-11, and BC3-31. These three lines have suppressed phenotypes with high levels of $\mathrm{BC} 1$ protein expression (Fig. 2). The suppression of phenotype in the BC3-11 line is associated with a mutated BCl gene (Duan 1996). Transgenic tobacco plants from these lines $\left(T_{1}\right.$ and $T_{2}$ generations) showed one of the following responses after inoculation: (i) no visible symptoms throughout the life of the plants, which were indistinguishable from uninoculated plants (Fig. 3D); (ii) vein chlorosis and mottling on early leaves after exposure to viruliferous whiteflies but subsequent growth with a marked remission of symptoms, consistent with significant reduction in virion detection (Fig. 4); (iii) a marked delay in the development of symptoms for several weeks after exposure to viruliferous whiteflies, with new growth showing typical TMoV symptoms (Fig. 5); and (iv) stunting, mottling, and vein chlorosis of leaves, typical symptoms associated with $\mathrm{TMoV}$ infections in nontransformed tobacco (Fig. 3A and C).
In all our infectivity tests with these three lines expressing mutated $\mathrm{BC} 1$ protein or proteins, a number of plants showed no symptoms on the leaves after exposure to viruliferous whiteflies for a 72-h inoculation period (Tables 1 and 2). The high rate of infectivity in the nontransformed control plants (94\%) and in the BVI transgenic plants (97\%) (Table 1) indicated that the inoculation conditions were typically suitable for disease development in susceptible plants. Some of the plants from these three lines initially showed disease symptoms similar to those of infected nontransformed tobacco but showed remission of symptoms in subsequent growth. ELISA of plants from one of these lines, transgenic for the truncated, recombination form of $B C 1$ gene $(B C 1 \mathrm{At} / \mathrm{r})$, indicated a suppression of TMoV levels in the upper leaves of these plants (Fig. 4). Such limitations in disease development have often been reported in studies of transgenic plants expressing viral sequences (Lomonossoff 1995).

Viral resistance evaluations with $\mathrm{TMoV}$ were done under a range of conditions in order to test the limits of the resistance. Experiments involving continuous inoculation pressure were
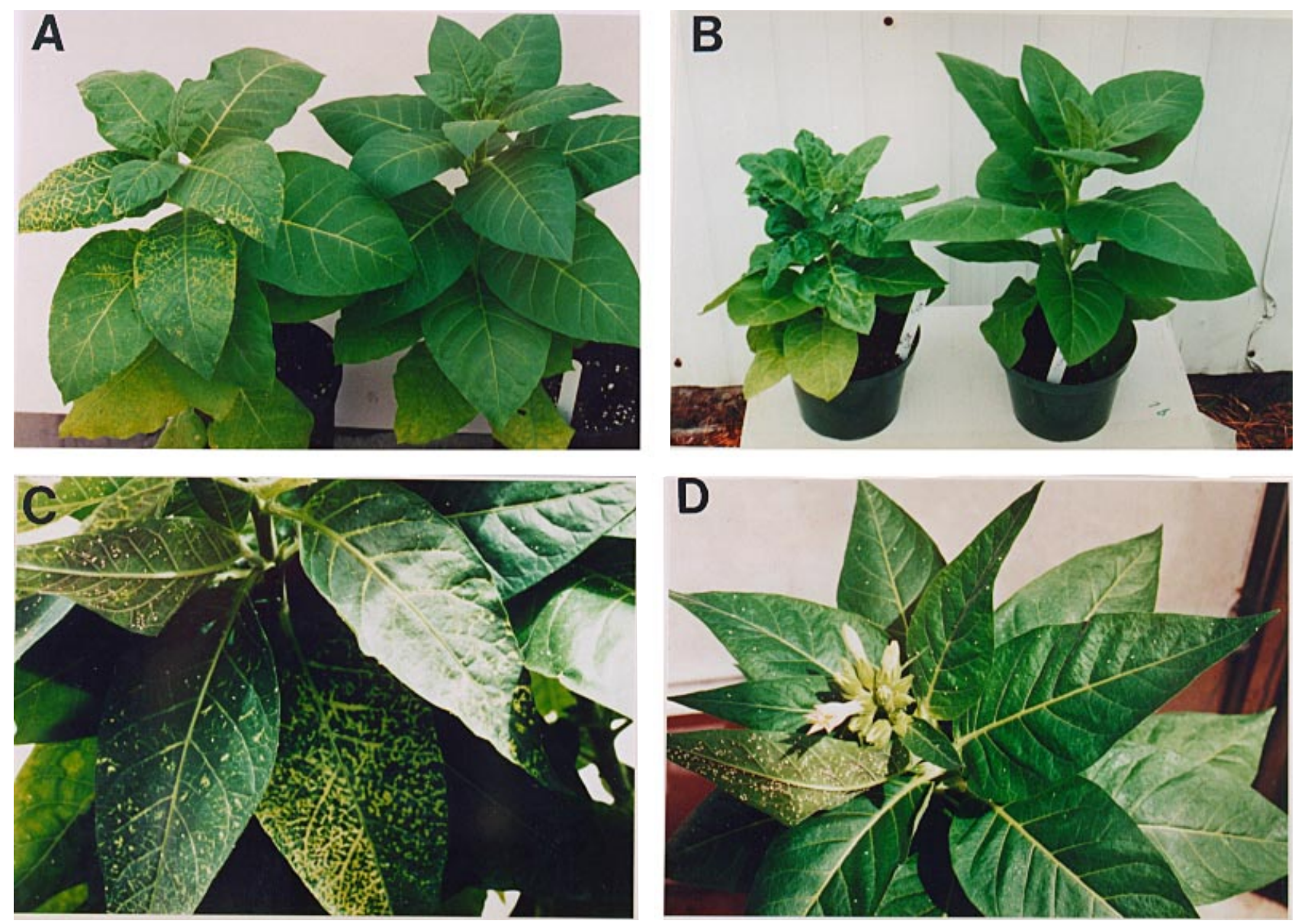

Fig. 3. Resistance of $\mathrm{T}_{2}$ transgenic tobacco plants (Nicotiana tabacum cv. Xanthi) to tomato mottle geminivirus (TMoV) and cabbage leaf curl geminivirus (CabLCV) infections. Transgenic tobacco plants expressing BC1 protein (Fig. 2) were challenged with TMoV or CabLCV transmitted by whiteflies. Nontransformed plants (A [left] and $\mathbf{C}$ ) and a susceptible transgenic plant (B [left]) show typical disease symptoms of virus infection, whereas the resistant transgenic plants are free of disease symptoms (A [right], B [right], and D). A, Nontransformed plant (left) and resistant transgenic plant from line BC3-11-6 exposed to TMoV-viruliferous whiteflies for $72 \mathrm{~h}$ at the nine-leaf stage, photographed 50 days after exposure. B, Susceptible transgenic plant from line BC3-6-3 (left) and resistant transgenic plant from line BC3-11-6 exposed to CabLCV-viruliferous whiteflies for $72 \mathrm{~h}$ at the seven- to nine-leaf stage, photographed 40 days after exposure. C and D, Nontransformed plant (C) and resistant transgenic plant from line BC3-11-6 (D) continuously challenged with TMoV-viruliferous whiteflies for 3 months, photographed 80 days after the start of the exposure. 
done with numerous whiteflies per plant (Figs. 3C and D), and the leaves of the test plants were shaken once a day to force the whiteflies to move about the plants. One round of testing was done from March to June in a non-air-conditioned greenhouse where the temperature often exceeded $40^{\circ} \mathrm{C}$ at midday from April to June. The whiteflies thrived under these conditions, and susceptible plants showed fully developed TMoV symptoms, indicating that the high temperatures did not result in heat therapy. Under continuous inoculum pressure and extreme temperature, a significant delay in symptom development was observed in a number of $\mathrm{T}_{2}$ plants (Fig. 5). In addition, a number of the $T_{2}$ progeny of transgenic tobacco line BC3-11-6, expressing mutated BC1 protein (BC1At/r), appeared free of visible symptoms throughout the 3-month exposure to thousands of viruliferous whiteflies carrying TMoV (Fig. 3D). ELISA of these virus-challenged transgenic plants indicated undetectable to very low levels of TMoV (data not shown). Positive ELISA readings (three times the background level) were always correlated with virus symptoms in tests of more than 300 samples.

Under the conditions described above, the test plants showed heat stress and damage due to extensive whitefly feeding. In order to avoid these complications in the evaluation of geminivirus resistance, other resistance tests were done with a 72-h inoculation period with viruliferous whiteflies (approximately 100 per plant) adapted to tobacco and under more moderate temperatures in an air-conditioned greenhouse (Fig. 3A and B; Fig. 4; Tables 1-3). Bedford et al. (1994) tested the geminivirus transmission efficiencies of the biotype $\mathrm{B}$ whitefly and found that 20 insects per plant resulted in $100 \%$ virus transmission in most tests. S. Webb and J. E. Polston (unpublished data) found that 40 viruliferous whiteflies per plant resulted in a $100 \%$ rate of infection with TMoV. A number of transgenic plant lines showed resistance under a range of inoculation tests and at inoculation pressures exceeding those expected in the field.

Some of the variation in resistance to $\mathrm{TMoV}$ in the three lines of transgenic tobacco (Tables 1 and 2; Fig. 5) is likely to be attributable to the segregation of the multiple transgene copies. Selected $\mathrm{T}_{1}$ lines tested for resistance were analyzed by Southern blots for transgene copy number (Table 2). We did not resolve whether resistance in lines with a single copy of

Table 2. Assessment of resistance to tomato mottle geminivirus in $T_{2}$ transgenic tobacco plants expressing the $B C 1$ open reading frame

\begin{tabular}{lccc}
\hline Plant line & $\begin{array}{c}\text { Transgene } \\
\text { copy } \\
\text { number }\end{array}$ & $\begin{array}{c}\text { No. of diseased } \\
\text { plants/no. of } \\
\text { inoculated plants }\end{array}$ & $\begin{array}{c}\boldsymbol{A}_{\mathbf{4 0 5} \text { value }}^{\mathrm{b}} \text { of } \\
\text { diseased plants/ } \\
\text { asymptomatic } \\
\text { plants }\end{array}$ \\
\hline Nontransformed & 0 & $6 / 6$ & $0.642 / \ldots$ \\
BC3-6-4 & 3 & $1 / 6$ & $0.327 / 0.012$ \\
BC3-11-6 & 1 & $3 / 7$ & $0.347 / 0.008$ \\
BC3-31-1 & 3 & $1 / 6$ & $0.969 / 0.011$ \\
BC3-31-3 & 4 & $4 / 6$ & $0.447 / 0.007$ \\
BC3-31-5 & 5 & $0 / 7$ & $\ldots / 0.009$ \\
BC3-31-7 & 4 & $2 / 6$ & $0.782 / 0.010$ \\
\hline
\end{tabular}

a The transgenic (kanamycin-resistant) and control plants at the sevento nine-leaf stage were exposed in a cage to viruliferous whiteflies for $72 \mathrm{~h}$, with approximately 100 whiteflies per plant. Plant lines and copy numbers refer to the $\mathrm{T}_{1}$ generation. Band patterns for $\mathrm{BC} 3-31-3$ and BC3-31-7 were not identical in Southern blots (data not shown).

${ }^{\mathrm{b}}$ Enzyme-linked immunosorbent assays were done 40 days after inoculation as described in Materials and Methods.

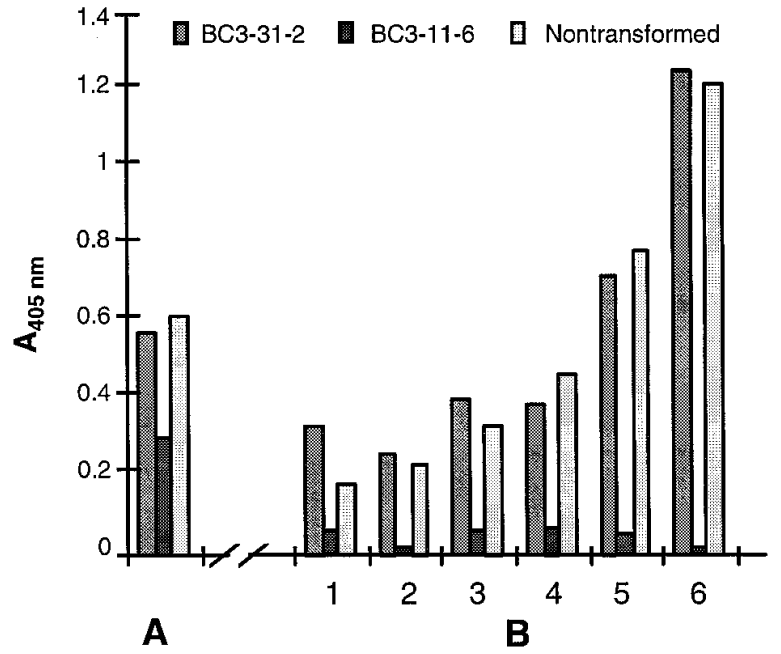

Fig. 4. Recovery phenomenon in transgenic plants expressing mutated $\mathrm{BC} 1$ protein (progeny of line BC3-11-6) infected with tomato mottle geminivirus, compared with progeny of a susceptible line (BC3-31-2) and nontransformed plants. Plants were inoculated for $72 \mathrm{~h}$. The virus concentration in infected plants was analyzed by enzyme-linked immunosorbent assay as described in Materials and Methods. A, Mean values of absorbance of samples of young symptomatic leaves of two plants from each of the three groups of test plants, 21 days after inoculation. B, Mean values of absorbance of samples of every third leaf of infected plants, from the oldest leaf (1) to the youngest newly expanded leaf (6), 85 days after inoculation. $A_{405}$ values for control plants (nontransformed tobacco) were $0.010 \pm 0.003$.

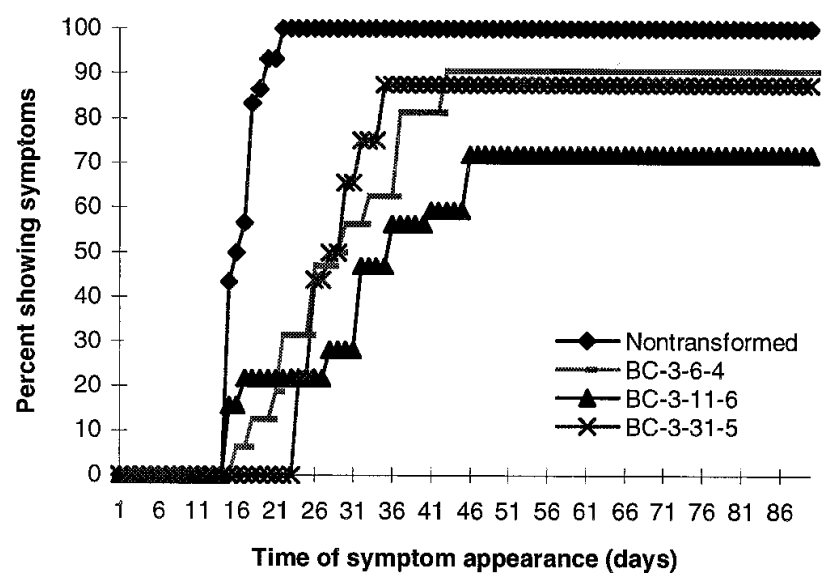

Fig. 5. Resistance to tomato mottle geminivirus in $T_{2}$ progeny of three transgenic tobacco plants expressing $\mathrm{BC} 1$ protein and having an asymptomatic phenotype, under continuous exposure to viruliferous whiteflies. Line BC3-11-6 contained a mutated form of the $B C 1$ gene. Transgenic (kanamycin-resistant) and nontransformed tobacco seedlings (32 plants per line) at the seven- to nine-leaf stage were exposed to viruliferous whiteflies in a greenhouse for more than 3 months (March to June). The whiteflies were raised on infected tobacco plants in the greenhouse and multiplied to a large population during the challenge period, increasing from about 100 per plant at the beginning of the period to thousands per plant at the end. The percentage of plants that showed systemic disease symptoms in each transgenic plant line was plotted against the time of symptom appearance (days numbered from the beginning of viruliferous whitefly exposure). 
the $B C 1$ transgene was associated with the homozygous or the heterozygous state. Highly TMoV-resistant transgenic plants were detected among the single- and multiple-copy $B C 1$ transgenic tobacco.

\section{Resistance to another geminivirus.}

The $\mathrm{T}_{2}$ progeny of highly TMoV-resistant $\mathrm{T}_{1}$ lines were tested against cabbage leaf curl geminivirus (CabLCV) (Genbank U65529 and U65530), a virus with approximately $70 \%$ nucleotide sequence similarity to TMoV. All the inoculated plants showed mild symptoms on the inoculated leaves, presumably due to whitefly feeding damage and to virus infection (chlorotic spots). Many of the resistant plants subsequently grew free of symptoms (Fig. 3B; Table 3), while in others the development of symptoms was significantly delayed (by 2 to 5 weeks). The level of CabLCV in the test plants was evaluated by ELISA (Table 3) and dot blot analysis (data not shown). The plants free of virus symptoms had ELISA readings below the level of virus detection. Plant lines with a high level of resistance to $\mathrm{TMoV}$ had a similar level of resistance to CabLCV (Table 3). The dot blot analysis involved separate sampling and testing of leaves, including inoculated leaves. The inoculated leaves tested positive in most cases, indicating that virus replication occurred in them, while upper leaves of plants free of systemic symptoms tested negative (data not shown). Resistance mediated by the mutated $B C l$ may involve the suppression of systemic movement of the virus.

\section{DISCUSSION}

\section{Geminivirus resistance.}

The spontaneously mutated $B C l$ transgene $(B C 1 \mathrm{At} / \mathrm{r})$ was previously shown (Duan 1996) to suppress the symptom-inducing effects of the $B C 1$ gene in transgenic plants containing one copy of each gene. Here we show that the $B C 1 \mathrm{At} / \mathrm{r}$ gene in transgenic tobacco (line BC3-11-6) also provides resistance to infection by two distinct geminiviruses, TMoV and CabLCV. Presumably the other lines, BC3-31-x and BC3-6-x, may contain another form or forms of spontaneously mutated $B C 1$ transgene (Duan 1996), because they also showed geminivirus resistance while expressing high levels of $\mathrm{BC} 1$ protein (Fig. 2 ). The symptomatic plants expressing $\mathrm{BC} 1$ protein were susceptible to TMoV (data not shown). The variation in resistance (Tables 2 and 3; Fig. 5) may be associated with the het-

Table 3. Assessment of resistance to cabbage leaf curl geminivirus in $\mathrm{T}_{2}$ transgenic tobacco plants expressing $B C l$

\begin{tabular}{lccc}
\hline Plant line & $\begin{array}{c}\text { Transgene } \\
\text { copy } \\
\text { number }\end{array}$ & $\begin{array}{c}\text { No. of diseased } \\
\text { plants/no. of } \\
\text { inoculated plants }\end{array}$ & $\begin{array}{c}\boldsymbol{A}_{\text {405 value of }} \\
\text { diseased plants/ } \\
\text { asymptomatic } \\
\text { plants }\end{array}$ \\
\hline BC3-6-3 & 5 & $4 / 5$ & $0.786 / 0.007$ \\
BC3-6-4 & 3 & $2 / 8$ & $0.690 / 0.010$ \\
BC3-11-6 & 1 & $3 / 8$ & $0.617 / 0.009$ \\
BC3-31-5 & 5 & $1 / 9$ & $1.065 / 0.013$ \\
BC3-31-7 & 4 & $0 / 5$ & $\ldots / 0.008$ \\
\hline
\end{tabular}

${ }^{a}$ Transgenic plant seedlings resistant to kanamycin (see Table 1) at the seven- to nine-leaf stage were exposed in a cage to viruliferous whiteflies for $72 \mathrm{~h}$, with approximately 100 whiteflies per plant. Plant lines and copy numbers refer to the $\mathrm{T}_{1}$ generation. Indirect enzyme-linked immunosorbent assay was used to assay the transgenic plants 52 days after inoculation as described in Materials and Methods. erozygous or homozygous state of the single-copy line (for example, seedlings of line BC3-11-6 segregated in the ratio of $3: 1$ on kanamycin selective medium) and the segregation of lines with multiple transgene copies (varied segregation rate on selective media; data not shown). Further genetic and biochemical dissections of transgene copies in these lines may resolve the potential correlation of the mutated versus nonmutated transgenes.

The resistance of certain lines to $\mathrm{CabLCV}$ is remarkable, since this virus is quite different from $\mathrm{TMoV}$. At the amino acid sequence level, the CabLCV BCl and TMoV BCl show $90 \%$ similarity and $80 \%$ identity. This degree of similarity and identity for this gene is typical of distinct New World bipartite geminiviruses. Sequence comparisons of the A component DNA of New World bipartite geminiviruses show CabLCV closely related to squash leaf curl virus, tomato golden mosaic virus, and bean golden mosaic virus (Brazil isolate) and distantly related to $\mathrm{TMoV}$ and similar geminiviruses, such as Abutilon mosaic virus, potato yellow mosaic virus, and sida mosaic virus (Abouzid et al. 1992a; Hiebert et al. 1996). TMoV has a narrow host range (Polston et al. 1993), while CabLCV has a very broad host range (Strandberg et al. 1991). The symptoms of CabLCV infection in tobacco (Fig. 3B) are much more severe than those induced by TMoV (Fig. 3A and $\mathrm{C})$. The resistance to $\mathrm{CabLCV}$ indicates that certain transgenic lines expressing mutated $\mathrm{BC} 1$ protein may have a broad spectrum of resistance to bipartite geminiviruses of the New World.

Many pathogen-derived resistance studies (Lomonossoff 1995) have found high virus specificity, with the exception of studies involving viral movement proteins (MP) (Lapidot et al. 1993; Beck et al. 1994; Cooper et al. 1995). Lapidot et al. (1993) demonstrated that transgenic tobacco with a mutant MP gene from tobacco mosaic virus (TMV) showed resistance to virus spread when inoculated with TMV or distantly related tobamoviruses. Beck et al. (1994) found that transgenic tobacco which expressed a mutated 13-kDa gene of white clover mosaic potexvirus (WCIMV), one gene within a triple gene block, was resistant to WCIMV and two other members of the genus Potexvirus (potato virus $\mathrm{X}$ and narcissus mosaic virus) and to potato virus $S$ (carlavirus). All these viruses have a triple gene block that codes for proteins necessary for cellto-cell movement. Cooper et al. (1995) reported that tobacco transgenic for defective TMV MP showed resistance to six taxonomically distinct RNA viruses. Our results with mutated TMoV $B C 1$ proteins extend the possibility of resistance to multiple DNA geminiviruses using mutated MP genes.

\section{MATERIALS AND METHODS}

Clone construction and plant transformation.

The $B C 1$ and $B V 1$ genes of TMoV (Abouzid et al. 1992b) were amplified from extracts of TMoV-infected tomato plants by PCR. The primers for $B C 1$ and $B V 1$, which were constructed with a HindIII restriction site, were 5'-CCCAACTTCGAGTTCGAAACTGC-3' and 5'-CCCAAGCTTAACGAAGTGTGTTTGAC-3' (for $B C 1$ ) and 5'-CCCAAGCTTTATCCAACTCAGCTGCA-3' and 5'-CCCAAGCTTGTAAGGCGTGTCAGAC-3' (for $B V 1$ ). The amplified $B C 1$ (nucleotides 1,278-2,308) and $B V 1$ (nucleotides 428-1,369) segments were cloned into the pGEM-T vector and then digested with $H$ indIII. The excised $B C 1$ and $B V 1$ segments were ligated into 
the unique HindIII site of the binary vector pKYLX71:35S ${ }^{2}$ (Maiti et al. 1993) to create the sense clones pKYsBC1 and pKYsBV1 and the antisense clones pKYasBC1 and pKYasBV1. Each of these clones was transformed into cells of Agrobacterium tumefaciens LBA 4404 (An et al. 1985). Nicotiana tabacum $\mathrm{cv}$. Xanthi was transformed using the leaf disk method with MS selective media containing cefotaxime (250 $\mu \mathrm{g} / \mathrm{ml})$ and kanamycin $(100 \mu \mathrm{g} / \mathrm{ml})$ (Horsch et al. 1985). Transformants were identified by PCR with specific primers, by ELISA with an NPTII (neomycin phosphotransferase II) ELISA Kit ( 5 Prime $\rightarrow 3$ Prime, Inc.), and by Southern blots. A total of $19 \mathrm{~T}_{0}$ plants containing pKYsBC1, 19 plants containing pKYasBC1, 20 plants containing $\mathrm{pKYsBV1}$, and five plants containing pKYasBV1 were selected and self-pollinated for $T_{1}$ seeds. $T_{1}$ seeds of selected lines were germinated individually on MS medium containing kanamycin $(100 \mu \mathrm{g} / \mathrm{ml})$, and the $T_{1}$ seedlings were transplanted into soil a month after germination.

\section{Sources of virus and whiteflies and inoculation of plants.}

The TMoV and cabbage leaf curl virus (CabLCV) cultures used in this study were the same ones reported by Abouzid (1992a,b). The inoculations with TMoV and CabLCV were carried out in Gainesville and Leesburg, Florida, respectively. The whiteflies used in this study came from a colony which has been confirmed to be biotype B of Bemisia tabaci by isozyme analysis performed by T. M. Perring (University of California, Riverside). They were maintained on collards (Brassica oleracea var. acephala $)$ in an insect rearing room $\left(25^{\circ} \mathrm{C}\right.$, 16-h photoperiod) at CFREC, Leesburg, Florida.

To assess TMoV resistance, whiteflies were reared on TMoV-infected tobacco plants in a greenhouse for several generations. The TMoV culture in a tomato plant was transmitted to tobacco plants (Nicotiana tabacum cv. Xanthi-NN) by whiteflies and maintained in tobacco. Transgenic tobacco seedlings selected by germination on kanamycin medium and nontransformed tobacco plants, both at the seven- to nine-leaf stage, were exposed in cages to viruliferous whiteflies for 72 $\mathrm{h}$, with approximately 100 whiteflies per plant. The whiteflies were disturbed once every $24 \mathrm{~h}$ to force them to move among the plants in order to provide a more uniform inoculation. For noncontinuous challenge, the whiteflies were killed with insecticide after inoculation, and the plants were transferred to another greenhouse and grown individually in pots for more than 3 months. For continuous challenge, the inoculated plants were maintained in a greenhouse and exposed to viruliferous whiteflies for a period of more than 3 months, and the whiteflies were disturbed every day. The population of viruliferous whiteflies increased as the challenge continued, and thousands of whiteflies per plant were present at the end of the test.

CabLCV was maintained in cabbage. Whiteflies were given access to CabLCV-infected cabbage for a period of $48 \mathrm{~h}$ and then used to inoculate tobacco plants at the seven- to nine-leaf stage for 3 to 4 days, with approximately 100 whiteflies per plant.

Detection of virion antigen and viral nucleic acids in plants. Geminivirus detection. ELISA for the detection of TMoV and CabLCV in tobacco leaf extracts was carried out with the triple-sandwich method as described by Cancino et al. (1995).
The wells of ELISA plates (Dynatech Labs, Inc., Chantilly, VA) were coated with polyclonal antiserum $1110(150 \mu \mathrm{l}$ per well) (Cancino et al. 1995) at a 1:1,000 dilution in coating buffer, $\mathrm{pH} 9.6$, and incubated at $37^{\circ} \mathrm{C}$ for $1 \mathrm{~h}$. The plates were washed three times with phosphate-buffered saline (PBS) containing $0.05 \%$ Tween 20 (pH 7.4), and extracts of leaf samples, homogenized at a 1:5 ratio of tissue to PBS, $\mathrm{pH} 7.4$, were added to the wells $(150 \mu \mathrm{l}$ per well). The plates were incubated at room temperature for 1 to $2 \mathrm{~h}$. After the plate wells were washed five to 10 times, $150 \mu \mathrm{l}$ of $3 \mathrm{~F} 7$ monoclonal antiserum (Cancino et al. 1995) at a 1:10,000 dilution was added to each well of the plates. The plates were incubated at room temperature for $1 \mathrm{~h}$ or at $4^{\circ} \mathrm{C}$ overnight and washed three times. Anti-mouse IgG conjugated with alkaline phosphatase (Sigma Chemical, St. Louis) at a 1:30,000 dilution was added to the plates $(150 \mu \mathrm{l}$ per well). The plates were incubated for 1 $\mathrm{h}$ and then washed three times. Then $150 \mu \mathrm{l}$ of substrate (1 $\mathrm{mg} / \mathrm{ml}, \rho$-nitrophenyl disodium phosphate, Sigma Chemical) in substrate buffer $(9.7 \%$ diethanolamine, Fisher Scientific, Fair Lawn, NJ) was added to each well, and the plates were incubated at room temperature. Absorbency readings (405 $\mathrm{nm})$ were taken on a Biotek EL 309 automated microplate reader (Bio-Tek Instrument Inc., Winooski, VT) at 1.5 to $2 \mathrm{~h}$.

Western blots. The subcellular fractions of the leaf extracts from transgenic and control plants (both TMoV-infected and noninfected tobacco) were prepared as described by Pascal et al. (1993). The proteins were separated by sodium dodecyl sulfate (SDS)-polyacrylamide gel electrophoresis, in a modification of the method described by Schagger and von Jagow (1987). The modified stacking gel was $4.5 \%$ polyacrylamide (based on the Laemmli system). After electrophoresis, the separated proteins were transferred to nitrocellulose. The BC1 proteins were immunoreacted with polyclonal antiserum (preabsorbed with partially purified tobacco proteins) against bacterium-expressed BC1 protein (Duan et al. 1995), and immunoreactions were detected with the Western-Light Chemiluminescent Detection System (TROPIX, Inc.).

Detection of viral nucleic acids. DNA was isolated by a modification of the method of Cocciolone and Cone (1993). Young tobacco leaf tissue $(0.2 \mathrm{~g})$ was ground in liquid nitrogen with $1.0 \mathrm{ml}$ of extraction buffer $(7 \mathrm{M}$ urea, $0.35 \mathrm{M} \mathrm{NaCl}$, $50 \mathrm{mM}$ Tris, $\mathrm{pH}$ 8.0, $20 \mathrm{mM}$ EDTA, 1\% Sarkosyl) in a mortar and pestle. This mixture was transferred to a 2-ml microcentrifuge tube and was extracted with $1: 1(\mathrm{v} / \mathrm{v})$ phenol/chloroform/isoamyl alcohol $(25: 24: 1)$. After centrifugation at 3,000 $\times g$ for $5 \mathrm{~min}$, the supernatant was extracted with chloroform/ isoamyl alcohol $(24: 1)$ and centrifuged at $6,000 \times g$ for $5 \mathrm{~min}$. An equal volume of isopropanol was added to the supernatant, and the mixture was stored at $-20^{\circ} \mathrm{C}$ for $1 \mathrm{~h}$. The nucleic acid was precipitated by centrifugation at $6,000 \times g$ for $20 \mathrm{~min}$ and resuspended in $0.4 \mathrm{ml}$ of TE $(10 \mathrm{mM}$ Tris- $\mathrm{HCl}, \mathrm{pH} 8.0,1 \mathrm{mM}$ EDTA) containing $0.5 \%$ Sarkosyl with $10 \mu \mathrm{g}$ of RNase. After incubation at $37^{\circ} \mathrm{C}$ for $30 \mathrm{~min}$, the mixture was extracted once with phenol/chloroform and then with chloroform and was reprecipitated with 0.1 volume of $3 \mathrm{M}$ sodium acetate and 2 volumes of $100 \%$ ethanol. DNA samples were resuspended in TE and stored at $-20^{\circ} \mathrm{C}$.

Dot blot assay of viral nucleic acid. Total nucleic acids were purified as described above from the lowermost leaf and the uppermost leaves, 54 days after inoculation, and spotted on $\mathrm{H}$ bond $\mathrm{N}^{+}$nylon membrane (Amersham) at $1 \mu \mathrm{g}$ per blot. Viral 
DNAs were detected by hybridization with ${ }^{32} \mathrm{P}$-labeled probe specific to DNA-A. Probe was made by random primed ${ }^{32} \mathrm{P}-$ labeling of CabLCV DNA-A with a Prime-a Gene labeling kit (Promega). Hybridization of blots (overnight at $65^{\circ} \mathrm{C}$ ) was in $6 \times \mathrm{SSC}(1 \times \mathrm{SSC}$ is $0.15 \mathrm{M} \mathrm{NaCl}$ plus $0.015 \mathrm{M}$ sodium citrate), $5 \times$ Denhardt's solution, and $0.5 \%$ SDS containing salmon sperm DNA $(0.1 \mathrm{mg} / \mathrm{ml})$. The blots were washed twice in $2 \times \mathrm{SSC}$ and $0.1 \% \mathrm{SDS}$ at room temperature for 10 min, once in $1 \times \mathrm{SSC}$ and $0.1 \%$ SDS, and once in $0.1 \times \mathrm{SSC}$ and $0.1 \% \mathrm{SDS}$ at $65^{\circ} \mathrm{C}$ for $15 \mathrm{~min}$, respectively.

\section{ACKNOWLEDGMENTS}

We thank Kris Beckham and Ellen Dickstein for technical assistance and A. Abouzid and G. Moore for helpful comments and suggestions. We thank A. G. Hunt, University of Kentucky, for supplying the pKYLX71:35S ${ }^{2}$ vector. Florida Agricultural Experiment Stations Journal Series Paper R-05611. This work has been supported by USDA-CBAG Special Programs Grants 93-34135-8607 and 92-34135-7456 and Florida Tomato Committee Grant/Contract 90153-C.

\section{LITERATURE CITED}

Abouzid, A. M., Hiebert, E., and Strandberg, J. O. 1992a. Cloning, identification, and partial sequencing of the genomic components of a geminivirus infecting the Brassicaceae. (Abstr.) Phytopathology 82: 1070 .

Abouzid, A. M., Polston, J. E., and Hiebert, E. 1992b. The nucleotide sequence of tomato mottle virus, a new geminivirus isolated from tomatoes in Florida. J. Gen. Virol. 73:3225-3229.

An, G., Watson, B. D., Stachel, S., Gordon, M. P., and Nester, E. W. 1985. New cloning vehicles for transformation of higher plants. EMBO J. 4:277-288.

Beachy, R. N. 1993. Introduction: Transgenic resistance to plant viruses. Semin. Virol. 4:327-328.

Beck, D. L., Vandolleweerd, C. J., Lough, T. J., Balmori, E., Voot, D. M., Andersen, M. T., Obrien, I. E. W., and Foster, R. L. S. 1994. Disruption of virus movement confers broad-spectrum resistance against systemic infection by plant viruses with a triple gene block. Proc. Natl. Acad. Sci. USA 94:10310-10314.

Bedford, I. D., Briddon, R. W., Brown, J. K., Rosell, R. C., and Markham, P. G. 1994. Geminivirus transmission and biological characteristics of Bemisia tabaci (Gennadius) biotypes from different geographical regions. Ann. Appl. Biol. 125:311-325.

Brown, J. K., and Bird, J. 1992. Whitefly-transmitted geminiviruses and associated disorders in the Americas and the Caribbean Basin. Plant Dis. 76:220-225.

Brown, J. K., Frohlich, D. R., and Rosell, R. C. 1995. The sweetpotato or silverleaf whiteflies: Biotypes of Bemisia tabaci or a species complex? Annu. Rev. Entomol. 40:511-534.

Cancino, M., Abouzid, A. M., Morales, F. J., Purcifull, D. E., Polston, J. E., and Hiebert, E. 1995. Generation and characterization of three monoclonal antibodies useful in detecting and distinguishing bean golden mosaic virus isolates. Phytopathology 85:484-490.

Cocciolone, S. M., and Cone, K. C. 1993. P1-Bh, an anthocyanin regulatory gene of maize that leads to variegated pigmentation. Genetics 135:575-588.

Cooper, B., Lapidot, M., Heick, J. A., Dodds, J. A., and Beachy, R. N. 1995. A defective movement protein of TMV in transgenic plants confers resistance to multiple viruses whereas the functional analog increases susceptibility. Virology 206:307-313.

Day, A. G., Bejarano, E. R., Buck, K. W., Burrell, M., and Lichtenstein, C. P. 1991. Expression of an antisense viral gene in transgenic tobacco confers resistance to the DNA virus tomato golden mosaic virus. Proc. Natl. Acad. Sci. USA 88:6721-6725.

Duan, Y. P. 1996. Molecular characterization of tomato mottle virus nonstructural protein genes and development of transgenic plants resistant to geminiviruses. Ph.D. thesis, University of Florida, Gainesville.
Duan, Y. P., Hiebert, E., Purcifull, D. E., and Powell, C. A. 1995. Serological detection of tomato mottle virus nonstructural proteins. (Abstr.) Phytopathology 85:1210.

Haley, A., Richardson, K., Zhan, X. C., and Morris, B. 1995. Mutagenesis of the $\mathrm{BC} 1$ and $\mathrm{BV} 1$ genes of African cassava mosaic virus identifies conserved amino acids that are essential for spread. J. Gen. Virol. 76:1291-1298.

Herskowitz, I. 1987. Functional inactivation of genes by dominant negative mutations. Nature 329:219-222.

Hiebert, E., Abouzid, A. M., and Polston, J. E. 1996. Whitefly-transmitted geminiviruses. Pages 277-288 in: Bemisia 1995: Taxonomy, Biology, Damage, Control and Management. Intercept Ltd., Andover, Hants, U.K.

Hong, Y., and Stanley, J. 1996. Virus resistance in Nicotiana benthamiana conferred by African cassava mosaic virus replication-associated protein (AC1) transgene. Mol. Plant-Microbe Interact. 9:219-225.

Horsch, R. B., Fry, J. E., Hoffmann, N. L., Wallroth, W., Eichholtz, D., Rogers, S. G., and Fraley, R. T. 1985. A simple and general method for transferring genes into plants. Science 237:1229-1231.

Ingham, D. J., Pascal, E., and Lazarowitz, S. G. 1995. Both bipartite geminivirus movement proteins define viral host range, but only BL1 determines viral pathogenicity. Virology 207:191-204.

Kunik, T., Salomon, R., Zamair, D., Zeidan, M., Michelson, I., Gafni, Y., and Czosnek, H. 1994. Transgenic tomato plants expressing the tomato yellow leaf curl virus capsid protein are resistant to the virus. Bio/Technology 12:500-504

Lapidot, M., Gafny, R., Ding, B., Wolf, S., Lucas, W. J., and Beachy, R. N. 1993. A dysfunctional movement protein of tobacco mosaic virus that partially modifies the plasmodesmata and limits virus spread in transgenic plants. Plant J. 4:959-970.

Lomonossoff, G. P. 1995. Pathogen-derived resistance to plant viruses. Annu. Rev. Phytopathol. 33:323-343.

Maiti, I. B., Murphy, J. F., Shaw, J. G., and Hunt, A. G. 1993. Plants that express a potyvirus proteinase gene are resistant to virus infection. Proc. Natl. Acad. Sci. USA 90:6110-6114.

Noris, E., Accotto, G. P., Tavazza, R., Brunetti, A., Crespi, S., and Tavazza, M. 1996. Resistance to tomato yellow leaf curl geminivirus in Nicotiana benthamiana plants transformed with a truncated viral C1 gene. Virology 224:130-138.

Noueiry, A. O., Lucas, W. J., and Gilbertson, R. L. 1994. Two proteins of a plant DNA virus coordinate nuclear and plasmodesmal transport. Cell 76:925-932.

Pascal, E., Goodlove, P. E., Wu, L. C., and Lazarowitz, S. G. 1993. Transgenic tobacco plants expressing the geminivirus BL1 protein exhibit symptoms of viral disease. Plant Cell 5:795-807.

Polston, J. E., Chellemi, D. O., Schuster, D. J., McGovern, R. J., and Stansly, P. A. 1996. Spatial and temporal dynamics of tomato mottle geminivirus and Bemisia tabaci (Genn.) in Florida tomato fields. Plant Dis. 80:1022-1028.

Polston, J. E., Hiebert, E., McGovern, R. J., Stansly, P. A., and Schuster, D. J. 1993. Host range of tomato mottle virus, a new geminivirus infecting tomato in Florida. Plant Dis. 77:1181-1184.

Sanford, J. C., and Johnson, S. A. 1985. The concept of parasite-derived resistance-Deriving resistance genes from the parasite's own genome. J. Theor. Biol. 113:395-405.

Schagger, H., and von Jagow, G. 1987. Tricine-sodium dodecyl sulfatepolyacrylamide gel electrophoresis for the separation of proteins in the range from 1 to $100 \mathrm{kDa}$. Anal. Biochem. 166:368-379.

Smith, D. R., and Maxwell, D. P. 1994. Requirement of the common region of DNA-B and the BL1 open reading frame of bean golden mosaic geminivirus for infection of Phaseolus vulgaris. Phytopathology 84:133-138.

Stanley, J., Frischmuth, T., and Ellwood, S. 1991. Defective viral DNA ameliorates symptoms of geminivirus infection in transgenic plants. Proc. Natl. Acad. Sci. USA 87:6291-6295.

Strandberg, J. O., Hiebert, E., Leibee, G. L., and Abouzid, A. 1991. A new geminivirus with a broad host range in the Brassicaceae. (Abstr.) Phytopathology 81:1244.

von Arnim, A., and Stanley, J. 1992a. Inhibition of African cassava mosaic virus systemic infection by a movement protein from the related geminivirus tomato golden mosaic virus. Virology 187:555-564.

von Arnim, A., and Stanley, J. 1992b. Determinants of tomato golden mosaic virus symptom development located on DNA B. Virology 186: 286-293. 